\title{
Local Phenotypic Variation in Amphibian-killing Fungus Predicts Infection Dynamics
}

\author{
Carolina Lambertini*,1, C. Guilherme Becker², Thomas S. Jenkinson³, \\ David Rodriguez ${ }^{4}$, Domingos da Silva Leite ${ }^{5}$, Timothy Y. James ${ }^{3}$, \\ Kelly R. Zamudio ${ }^{6}$, Luís Felipe Toledo ${ }^{1}$
}

${ }^{1}$ Laboratório de História Natural de Anfíbios Brasileiros (LaHNAB), Departamento de Biologia Animal, Instituto de Biologia, Universidade Estadual de Campinas, Campinas, São Paulo, 13083-862, Brazil.

${ }^{2}$ Departamento de Zoologia, Universidade Estadual Paulista, Rio Claro, São Paulo, 13506-900, Brazil.

${ }^{3}$ Department of Ecology and Evolutionary Biology, University of Michigan, Ann Arbor, Michigan, 48109, United States of America.

${ }^{4}$ Department of Biology, Texas State University, San Marcos, Texas, 78666, United States of America.

${ }^{5}$ Departamento de Genética, Evolução e Bioagentes, Instituto de Biologia, Universidade Estadual de Campinas, Campinas, São Paulo, 13083-862, Brazil.

${ }^{6}$ Department of Ecology and Evolutionary Biology, Cornell University, Ithaca, New York, 14850, United States of America.

*Corresponding author: LaHNAB, Departamento de Biologia Animal, Instituto de Biologia, Universidade Estadual de Campinas, Campinas, 13083-862, São Paulo, Brazil. Tel.: +55 19 3521-6323. E-mail address: lambertini.carol@gmail.com 
Article history:

Received 29 May 2015

Revision received 21 August 2015

Accepted 07 September 2015

Corresponding editor:

Matthew C Fisher 


\begin{abstract}
Environmental factors can limit the distribution of organisms if they are not able to respond through phenotypic plasticity or local adaptation. Batrachochytrium dendrobatidis $(B d)$ is a broadly distributed pathogen, which shows spatially patterned genotypic and phenotypic variation; although, information on the functional consequences of this variation on disease dynamics in natural hosts is limited. We genotyped and quantified variation in $B d$ phenotypes across an elevational gradient and quantified host infection dynamics at each site. All $B d$ strains were members of the global panzootic lineage yet differed in phenotype. We hypothesize that this phenotypic variance results from adaptive processes due to the interaction between pathogen, hosts, and environment. We detected a correlation between zoospore and zoosporangia sizes and a positive association between zoosporangia size and $B d$ prevalence. Given that $B d$ phenotype predicted disease status in our wild populations, we developed an index to identify critical environments where the fungus could be more deleterious.
\end{abstract}

Keywords: Chytridiomycosis, morphology, zoospore, zoosporangium, disease dynamics, infection indices 


\section{Introduction}

Organisms that have broad distributions must contend with highly variable environmental factors that affect their fitness (Thoday, 1953; Hall et al.1992; Travis, 1994). Depending on their degree of tolerance, many environmental factors such as temperature, seasonality, precipitation, humidity, and elevation can limit organismal distributions or directly affect their performance and probability of persistence (Ignoffo, 1992; Inglis and Sagripanti, 2006). Organisms use a number of mechanisms to respond to these environmental challenges that fall along a continuum from phenotypic plasticity to microevolution (Reed et al. 2010). Independent of the mechanism, the result is phenotypic or genetic variation that has functional consequences not only for species persistence, but also for interactions with other species in the community (Agrawal, 2001; Smits et al. 2006). Functionally significant phenotypic changes will be especially important in interactions between hosts and pathogens, because they can change patterns of disease dynamics in populations. For example, the pathogenic fungus Cryptococcus neoformans is capable of producing significantly larger cells when infecting particular hosts as a means of evading host immune responses (Zaragoza et al. 2010), thus altering infection rates in host populations. While we know that pathogens often vary in phenotype (Brown and Barker, 1999; Drenkard and Ausubel, 2002; Matz et al. 2005; Smits et al. 2006), we know less about how those phenotypes translate into patterns of disease in natural populations.

The amphibian-killing fungus, Batrachochytrium dendrobatidis (hereafter $B d$ ), causes chytridiomycosis, which is a main factor contributing to amphibian population declines and extinctions worldwide (Wake and Vredenburg, 2008; Fisher et al. 2012). Bd is broadly distributed, infects a wide range of hosts (Olson et al. 2013; Valencia-Aguilar et al. 2015), and persists across a broad temperature range (Piotrowski et al. 2004; Woodhams et al. 2008; Becker and Zamudio, 2011). These characteristics increase its 
success as a host-generalist pathogen. Distribution models based on climatic and topographic variables have been used to predict the current and future (Ron, 2005; Rödder et al. 2008, 2009, 2010; Puschendorf et al. 2009; Murray et al. 2011; Rohr et al. 2011; Liu et al. 2013; James et al. 2015) ranges of this pathogen. These models infer the potential occurrence of $B d$ at continental and global scales but only indirectly predict the likelihood of disease outcomes. Additionally, we know that phenotypic variation in $B d$ can be explained by life history trade-offs (Woodhams et al. 2008) and potential changes in gene expression conferred by aneuploidy or other genomic features (Rosenblum et al. 2013), but rarely are we able to link these changes in phenotype to community level disease epidemiology. These interactions between environmental and genetic control are evident in the many field surveys of pathogen prevalence in wild populations (Burdon et al. 1977; Vercelli, 2004; Hunter, 2005). For example, models predict that $B d$ has a higher probability of occurrence at high elevations, where mean temperatures and cloud cover provide better (or ideal) conditions for its growth (Piotrowski et al. 2004; Pounds et al. 2006). However, not all high elevation sites appear to respond equally to $B d$ infection (Lips, 1998; La Marca et al. 2005; Brem and Lips, 2008; Kriger and Hero, 2008; Gründler et al. 2012).

$B d$ strains can be genetically subdivided into enzootic and panzootic lineages (Farrer et al. 2011; Schloegel et al. 2012; Rosenblum et al. 2013) that differ in chromosomal copy number and virulence (Farrer et al. 2013; Rosenblum et al. 2013). Bd strains also vary in phenotypes related to transmission. For example, among strains, zoospore sizes vary from 2 to $6 \mu \mathrm{m}$ (Longcore et al.1999; Fisher et al. 2009; Schloegel et al. 2012), and zoosporangium sizes vary from 15 to $68 \mu \mathrm{m}$ (Fisher et al. 2009; Farrer et al. 2011; Flechas et al. 2013). Further, zoosporangium size is correlated to virulence 
(Fisher et al. 2009), and zoospore size is correlated to DNA content (Schloegel et al. 2012), suggesting that phenotype and virulence may also be related.

Knowledge of phenotypic variation in $B d$ and its functional consequences for disease dynamics is limited; thus, understanding variance in $B d$ phenotypes across varying environments could be key to investigating the evolution of $B d$ virulence at multiple spatial scales (Farrer et al. 2013). Here, we genotyped and quantified phenotypes of $B d$ strains isolated across a $500 \mathrm{~m}$ elevational range in the Brazilian Atlantic Forest. First, we predicted that environmental variation across the elevational gradient would explain infection dynamics across populations. Second we hypothesized that $B d$ would vary predictably in phenotypes (such as zoospore and zoosporangium sizes) that are important for disease transmission. Finally, we predicted that those changes in phenotype would affect community disease outcomes. Our study standardized host amphibian species, breeding habitat, latitude, and season, reducing extrinsic factors that might confound the association between the environment, pathogen phenotypes, and infection dynamics in these populations. We discuss the implications of our results using a predictive index that could be applied in disease monitoring of other amphibian communities infected by $B d$.

\section{Methods}

Study site and field sampling

We sampled five Atlantic Coastal Forest streams along an elevational gradient (from 200 to 700 meters above sea level [a.s.1.]) (Table 1) at the Parque Estadual da Serra do Mar, Núcleo Itutinga-Pilões. The sampled streams were located in the municipalities of Biritiba-Mirim and Bertioga, São Paulo state, in southeastern Brazil. All streams were located in pristine forest and had approximately the same width, water flow, and canopy 
cover. We collected 129 adults of our focal host species, Hylodes phyllodes, with a minimum of 14 adults per site (Table 1 ). We also collected up to $10 H$. phyllodes tadpoles at each elevation for $B d$ isolation. All field collections were approved by Instituto Chico Mendes de Conservação da Biodiversidade (ICMBio: 26972-1) and Instituto Florestal (COTEC/SMA: 260106 - 011.309/2011).

$B d$ infection intensity and prevalence

For $B d$ detection and quantification of local prevalence and infection intensity, we collected adult $H$. phyllodes and maintained them individually in plastic bags to avoid cross-contamination. At least five individuals per locality were kept as voucher specimens and deposited at the Museu de Zoologia "prof. Adão José Cardoso" (ZUEC), Instituto de Biologia, Universidade Estadual de Campinas (UNICAMP), São Paulo, Brazil. At the time of capture, we swabbed all adult $H$. phyllodes following standard field sampling protocols for $B d$ detection (Hyatt et al. 2007). Each swab was placed in a dry and sterile $1.5 \mathrm{ml}$ cryovial in the field and stored at $-20^{\circ} \mathrm{C}$ in the laboratory until diagnostic analyses were conducted. For detection and quantification of $B d$ zoospores, we first extracted DNA from swabs using $50 \mu \mathrm{l}$ of PrepMan ULTRA® (Life Technologies) and then quantified infection intensities for each frog using a TaqMan ${ }^{\circledR}$ qPCR Assay (Life Technologies) (Boyle et al. 2004), with modifications described in Kriger et al. (2006) and Lambertini et al. (2013). Briefly, we used strain CLFT 023 as a quantitative standard for the qPCR reactions (Longo et al. 2013). The strain was grown in 1\% tryptone in Petri dishes. After growth plates were flooded with distilled water, zoospores were collected and counted with a hemocytometer, before DNA extraction with $100 \mu$ l of PrepMan ULTRA® (Boyle et al. 2004; Lambertini et al. 2013). We serially diluted (1:10) the genomic extract to generate the standard curve for our qPCR reactions $\left(10^{3}\right.$ to $10^{-1}$ genomic equivalents - 
g.e.). We considered field collected samples positive for $B d$ results when at least one g.e. was detected (Kriger et al. 2007).

$B d$ phenotypes and genotypes

We screened up to ten $H$. phyllodes tadpoles from each elevation for possible $B d$ infection by examining their mouthparts (Knapp and Morgan, 2006; Lambertini et al. 2013). We used only tadpoles for $B d$ isolation because it is easier to identify infected individuals in the field by examining mouthpart depigmentation, and also because they typically carry higher $B d$ infection loads than adults (Vieira and Toledo, 2012). Animals showing signs of $B d$ infection were euthanized and oral tissues excised for confirmation of infection by the presence of zoosporangia using compound microscopy (Vieira and Toledo, 2012). The number of euthanized tadpoles varied depending on the number of infected individuals, but we had success in $B d$ isolation with five to ten euthanized tadpoles per locality. Mouthparts containing zoosporangia were dissected and mechanically cleaned by dragging in $1 \%$ tryptone culture medium and transferred to sterile plates containing $1 \%$ tryptone culture medium with G-penicillin $\left(200 \mathrm{mgl}^{-1}\right)$ and streptomycin sulfate (350 $\mathrm{mg}^{-1}$ ) (Vieira and Toledo, 2012). We grew $B d$ colonies for 1 week and then extracted the DNA from each pure culture for genotyping.

We genotyped five isolated strains, one from each elevation. DNA extraction followed published protocols (James et al. 2008) and we genotyped each individual by sequencing ten SNP markers using previously described primers and PCR protocols (Schloegel et al. 2012). Marker sequences were aligned by assembling contigs to reference sequences (Schloegel et al. 2012) and visually screened for polymorphisms using Sequencher 4.10.0. We specifically chose SNP markers that are diagnostic for the panzootic $B d$-GPL and the endemic $B d$-Brazil strains, the two major lineages that occur 
in southeastern Brazil. We also included markers 8009X2 and R6046, which differentiate panzootic strains of the $B d$-GPL clade into clades 1 or 2 (Schloegel et al. 2012; Rosenblum et al. 2013). DNA sequencing was conducted at the University of Michigan Sequencing Core Lab.

We measured three phenotypes from the five $B d$ strains collected from our elevational gradient: zoospore size, zoosporangium size, and growth rate (quantified by zoospore production in culture) (Fisher et al. 2009; Flechas et al. 2013). Each strain was inoculated into $15 \mathrm{ml} \mathrm{Falcon}{ }^{\circledR}$ tubes containing $5 \mathrm{ml}$ of liquid media composed of 1\% tryptone. All cultures were placed in a Biological Oxygen Demand (B.O.D.) incubator set at $21^{\circ} \mathrm{C}$ for $7 \mathrm{~d}$. At seven days, we photographed aliquots of each $B d$ strain in culture (two aliquots per slide) using optical microscopy at $1000 \mathrm{X}$ magnification with immersion oil. We took 60 photographs of each strain (30 photographs of each aliquot or more depending on the resolution of the pictures) and selected the largest zoospores and zoosporangia from each photograph. We then measured the diameter of the 60 largest zoospores and 60 largest zoosporangia in micrometers, using the software TSView ${ }^{\circledR}$.

To quantify strain-specific growth rate, we plotted zoospore production curves at a constant temperature $\left(17^{\circ} \mathrm{C}\right)$, with four replicates for each of the five $B d$ strains. We flooded plates with $10 \mathrm{~mL}$ of $1 \%$ tryptone liquid media; we then standardized the initial zoospore number at 450,000 zoospores by counting with a hemocytometer and diluting liquid cultures as necessary. We inoculated each strain in $50 \mathrm{~mL}$ Falcon® tubes with 25 $\mathrm{mL}$ of liquid media (tryptone $1 \%$ ) and incubated all strains in a B.O.D. incubator at $17^{\circ} \mathrm{C}$. $B d$ growth rate was quantified by qPCR every three days over a period of nine days. At each sampling period, $100 \mu \mathrm{l}$ of each inoculum was centrifuged at 11,269 $\mathrm{g}$ for $10 \mathrm{~min}$, and the supernatant removed. DNA extractions were performed on the remaining 
zoospore pellets by using $100 \mu \mathrm{l}$ of PrepMan ${ }^{\circledR}$ ULTRA. DNA extraction and qPCR analyses followed standard protocols (Boyle et al. 2004; Lambertini et al. 2013).

Disease indices

We developed two formulae to compare strain-specific phenotypes (zoospore and zoosporangium sizes) for each site where a $B d$ strain was collected, with measures of local disease dynamics at those same sites (i.e. prevalence, $\%$ of infected individuals, and infection intensity, number of zoospore DNA equivalents):

$$
\text { Size Index (SI): } \quad S I=\frac{\overline{\mathrm{x}} \mathrm{z}+10 \overline{\mathrm{X}} \mathrm{z}}{2}
$$

Where, $\mathrm{Z}=$ Zoosporangium size, $\mathrm{z}=$ Zoospore size.

$$
\text { Infection Index (II): } \quad I I=\frac{\operatorname{Prev}+\left(\frac{\overline{\mathrm{x}} \mathrm{Load}}{2}\right)}{2}
$$

Where, Prev $=$ Prevalence $(\%)$, Load $=$ Infection Intensity

We multiplied the $\bar{X} z$ by 10 and divided the $\bar{X}$ Load by 2 to standardize the observed values for both indices, so the estimated values were at the same order of magnitude.

\section{Statistical analyses}

We used linear regressions to test for the effect of elevation on host $B d$ infection prevalence and intensity. We used a Pearson correlation to test for an association between $B d$ prevalence and infection intensity, as well as between zoospore size and zoosporangium size. To test if zoospores and zoosporangia varied significantly in size among strains, we performed analyses of variance (ANOVA). We followed these analyses by comparing how zoospores and zoosporangia varied in average size across the 
elevation gradient using General Linear Models with ordinary least squares (hereafter GLM).

We used MANOVA to test whether $B d$ growth rates differed among strains across time. We used stepwise GLMs (exclusion cutoff $P<0.10$; inclusion cutoff $P<0.25$ ) to test for factors (elevation, absolute $B d$ growth at day 9, and zoosporangia sizes) and onelevel interactions among those variables, that potentially predict $B d$ infection prevalence and intensity. Finally, we performed a linear regression to test for the effect of size index on infection index and visually inspected the residuals for normal distribution. We used JMP-SAS v.10. to perform statistical analyses (SAS 2010).

\section{Results}

Overall $B d$ prevalence in wild collected frogs across all five populations ranged between 58.33 to $92.85 \%$, with mean infection intensity ranging between 64.75 and 862.63 zoospore equivalents (Table 1). We found no significant influence of elevation on either $B d$ infection prevalence $\left(F_{[1,3]}=0.028, R^{2}=0.009, P=0.877\right.$; Fig S1A $)$ or intensity $\left(F_{[1,3]}\right.$ $=0.006, R^{2}=0.002, P=0.942$; Fig S1B). Field estimates showed a significant positive correlation between $B d$ prevalence and infection intensity at our five sites $(r=0.977, P=$ 0.004) (Fig 1).

Genotyping across the elevational gradient revealed that the five strains were genetically distinct but all belonged to the global pandemic lineage, clade 2 (Bd-GPL-2), the globally dispersed and hypervirulent lineage (Schloegel et al. 2012; Rosenblum et al. 2013) (Table S1). Zoospores ranged between 1.30 and $6.34 \mu \mathrm{m}$ in diameter (Table 1) and zoospore sizes differed significantly among strains $\left(F_{[4,295]}=33.855, P<0.001 ;\right.$ Fig S2A $)$. Zoosporangia ranged between 10.38 and $45.05 \mu \mathrm{m}$ in diameter (Table 1), and also differed among strains $\left(F_{[4,295]}=35.000, P<0.001\right.$; Fig S2B $)$ Even though $B d$ strains 
varied in zoospore size and zoosporangium size, elevation did not predict these differences in phenotypes (zoospore size: $F_{[1,3]}=0.065, P=0.815$; zoosporangium size: $\left.F_{[1,3]}=0.001, P=0.995\right)$. We detected a strong correlation between zoospore size and zoosporangium size $(r=0.936, P=0.019$; Fig 2$)$; therefore, we decided to only use zoosporangium size in downstream analyses. None of the other explanatory variables were cross-correlated.

Our stepwise GLM indicated that $B d$ infection prevalence and $B d$ infection loads are best explained by the sole effect of zoosporangium size ( $B d$ prevalence: $F_{[1,3]}=$ $16.518, R^{2}=0.846, P=0.027$, Fig $3 \mathrm{~A} ; B d$ load: $F_{[1,3]}=23.085, R^{2}=0.885, P=0.017$ Fig 3B). Both prevalence and load were not explained by any other combination of explanatory variables, including their interactions. Even though growth rate among $B d$ strains did not explain prevalence and infection intensity, we found significant variation in growth curves among the five focal strains (Repeated Measures ANOVA: Wilk's $\lambda=$ $0.010, d f=12, F=13.259, P<0.0001 ;$ Fig S3).

To explore a predictive tool that could potentially be used to identify critical areas of $B d$ pathogenesis, we produced a linear regression between Size Index and Infection Index at each site and detected a positive association $\left(F_{[1,3]}=19.713, R^{2}=0.867, P=\right.$ 0.021; Fig 4).

\section{Discussion}

The phenotypic diversity we found among field-collected $B d$ strains is surprisingly high given that genotypes of the five strains show that they are all members of the same clade (GPL 2), recently derived from a common ancestor (Rosenblum et al. 2013), and were collected along a $500 \mathrm{~m}$ elevational gradient (approximately $100 \mathrm{~m}$ elevational difference among populations). Nonetheless, the variation that we observed in zoospore and 
zoosporangium sizes falls within the range measured globally (Longcore et al. 1999; Fisher et al. 2009; Farrer et al. 2011; Schloegel et al. 2012; Flechas et al. 2013). This high phenotypic diversity among closely-related populations in near proximity could be due to intrinsic plasticity or adaptive change. However, the strains were brought to the lab and cultured under identical conditions, with no noticeable change in phenotypes over time. Therefore, we infer that the observed phenotypic variation is likely genetically based.

Although some studies have found increased $B d$ infections at higher elevations (Walker et al. 2010; Piovia-Scott et al. 2011; Gründler et al. 2012), our stepwise regressions showed that elevation is not a significant explanatory factor for either prevalence or infection intensity. Thus our data do not corroborate our first hypothesis. In the tropics, the proposed mechanism for this positive relationship between disease and elevation has been that cooler temperatures at higher elevations provide optimal conditions for fungal growth (Longcore et al. 1999; Piotrowski et al. 2004, Kriger and Hero, 2008), which then increases host exposure leading to higher prevalence (Gründler et al. 2012). Clearly, infection prevalence and intensity are complex measures, likely affected by many interrelated variables, and thus a simple relationship between elevation and disease should not be expected.

Our data also do not support our second hypothesis that elevation impacts specific phenotypes that are important for disease outcomes. Although we found significant variation among our five strains in growth rate, zoospore size, and zoosporangium size, none of these variables were significantly correlated with elevation. Fisher et al. (2009) suggested that morphological traits of $B d$ strains are under selection to adapt to environmental conditions. The phenotypic variation that we found could be explained by some unmeasured environmental factor (e.g., temperature, cloud cover, humidity) or could be attributed to micro evolutionary changes in the chytrid itself. Morphological 
adaptations are common in pathogenic microorganisms, which can rapidly evolve changes in cell size, shape and volume to ensure their survival (Lambowitz et al. 1983; Hajek and Leger, 1994; Ballou et al. 2010; Voyles et al. 2014). Such adaptive mechanisms may facilitate the survival and spread of the pathogen in local hosts (Kronstad et al. 2011).

Our data do support our third hypothesis in that we found a significant correlation between pathogen phenotype and local host infection dynamics. This correlation must be at some level mediated by pathogen performance (e.g., virulence, resilience, longevity, or transmission ability) (Fisher et al. 2009), which increases host infection rates in nature. We know that zoospore size is correlated with DNA content and potentially ploidy (Schloegel et al.2012); thus it is possible that higher overall zoospore size is correlated with underlying genomic changes which influence the infection ability of the fungus (Pavelka et al. 2010). A second potentially advantageous functional characteristic of larger zoospores is increased lifespan. A model by Mitchell et al. (2008) showed that longer zoospore lifespan was a positive predictor of virulence and increased likelihood of host extinction. Additionally, Fisher et al. (2009) detected significantly lower virulence in one $B d$ isolate that showed smaller zoosporangium size, and they inferred that larger zoosporangia may also cause greater damage to host skin than smaller ones, thus increasing the negative effects on hosts. Our results support the hypothesis that having a larger zoospore and zoosporangia size confers advantages in the host infection process.

Growth rate is another phenotypic trait linked with $B d$ virulence (Fisher et al. 2009; Pavelka et al. 2010; Schloegel et al. 2012; Langhammer et al. 2013). In a study of a highly susceptible host, Rana cascadae, a virulent $B d$ strain showed high optical density but lower exponential growth, indicating that the capacity of growing in high density can be an important aspect of $B d$ virulence (Piovia-Scott et al. 2014). However, $B d$ growth in vitro was not consistent with the observed growth in susceptible hosts (Piovia-Scott et al. 
2014). This factor may have influenced our results, as we also did not find associations between growth rate and host infection dynamics. We do not know how many zoospores a single zoosporangium releases. However, we did not find a correlation between the growth rate of the strains and zoosporangium size, therefore we did not observe a direct trade-off between zoospore size and zoospore number. Combined, these data indicate that the aspect of virulence that is selected for in populations is not the growth rate, but quality of the zoospores given the selective environment for each population.

To date, no other study has related population-level phenotypic variation in $B d$ with disease outcomes in wild anuran populations. We demonstrated a relationship between pathogen morphology and epidemiological variables, and we hypothesize that phenotypic variation among $B d$ strains reflects adaptation to local environments that enhances $B d$ transmission in those populations. We propose two indices that incorporate these variables, as a potential tool for identifying areas where amphibians may be more threatened by $B d$. The indices are based on $B d$ prevalence, infection intensity, and phenotype, all easily obtainable measures in studies of $B d$ in natural populations. The indices reflect correlations that we found between phenotype and host infection dynamics in wild populations; therefore, they may aid in identifying areas with higher prevalence and infection intensity through morphometric analyses. Such mapping could be readily applied towards conservation actions worldwide.

In Central and South America, $B d$ shows the genetic signature of recent range expansion of a clonal lineage, the global pandemic lineage (GPL) (James et al. 2009; Farrer et al. 2011). Though all of the strains in the current study are closely related GPL genotypes (Jenkinson et al. in review), the strains we isolated show dramatic differences in gross morphology and growth rate. The $B d$ GPL lineage also has a highly dynamic genome with variation in chromosomal copy number, aneuploidy, and loss of 
heterozygosity (Rosenblum et al. 2013), characteristics that are linked to high virulence in $B d$ strains in North American frog populations (Piovia-Scott et al. 2014). This variation, in turn, can be expressed through high phenotypic variation and may be a consequence of local selective processes leading to increases in pathogen fitness, thus contributing to the success of a highly generalist pathogen. Future work should be directed at understanding how the underlying phenotypic variation we observed is related to genomic changes in strains.

Our results support the hypothesis that interactions between pathogen morphological traits and host infection can shape disease dynamics and outcome, and they highlight the importance of future studies focused on the functional consequences of pathogen phenotypic variability in natural host populations.

\section{Acknowledgements}

We thank Amanda Piffer, Ana Beatriz Carollo, Conrado A. Vieira, Daniel M. Mendes, Diogo Moraes, Luiz Fernando M. de Lima, Mirtis M. G. Ferraz, Paula P. Morão and Tamilie Carvalho for field and laboratory assistance. Alexandre F. R. Missassi for feedback on the manuscript. Financial support was provided by grants from the National Science Foundation (OISE-1159513, DBI-0905810), Fundação de Amparo à Pesquisa do Estado de São Paulo (FAPESP: 2011/51694-7; 2012/04160-0; 2012/51694-7), and Conselho Nacional de Desenvolvimento Científico e Tecnológico (CNPq: 405285/20132). 


\section{References}

Agrawal, A.A., 2001. Phenotypic plasticity in the interactions and evolution of species. Science 294, 321-326.

Ballou, E.R., Nichols, C.B., Miglia, K.J., Kozubowski, L., Alspaugh, J.A., 2010. Two CDC42 paralogues modulate Cryptococcus neoformans thermo tolerance and morphogenesis under host physiological conditions. Molecular Microbiology 75, 76780.

Becker, C.G., Zamudio, K.R., 2011. Tropical amphibian population experience higher disease risk in natural habitats. Proceedings of the National Academy of Sciences 108, 9893-9898.

Boyle, D.G., Boyle, D.B., Olsen, V., Morgan, J.A.T., Hyatt, A.D., 2004. Rapid quantitative detection of chytridiomycosis (Batrachochytrium dendrobatidis) in amphibian samples using real-time Taqman PCR assay. Diseases of Aquatic Organisms 60, 141-148.

Brem, F.M., Lips, K.R., 2008. Batrachochytrium dendrobatidis infection patterns among Panamanian amphibian species, habitats and elevations during epizootic and enzootic stages. Diseases of Aquatic Organisms 81, 189-202.

Brown, M.R.W., Barker, J., 1999. Unexplored reservoirs of pathogenic bacteria: protozoa and biofilms. Trends in Microbiology 7, 1-5.

Burdon, R.D., 1977. Genetic correlation as a concept for studying genotype-environment interaction in forest tree breeding. Sivae Genetica 26, 168-175.

Drenkard, E., Ausubel, F.M., 2002. Pseudomonas biofilm formation and antibiotic resistance are linked to phenotypic variation. Nature 416, 740-743.

Farrer, R.A., Weinert, L.A., Bielby, J., Garner, T.W., Balloux, F., Clare, F., Fisher, M. C., 2011. Multiple emergences of genetically diverse amphibian-infecting chytrids 
include a globalized hypervirulent recombinant lineage. Proceedings of the National Academy of Sciences 108, 18732-18736.

Farrer, R.A., Henk, D.A., Garner, T.W., Balloux, F., Woodhams, D.C., Fisher, M.C., 2013. Chromosomal copy number variation, selection and uneven rates of recombination reveal cryptic genome diversity linked to pathogenicity. PLoS Genetics $9,1-13$.

Fisher, M.C., Bosch, J., Yin, Z., Stead, D.A., Walker, J., Selway, L., Brown, J.P., Walker, L.A., Gow, N.A.R., Stajich, J.E., Garner, T.W.J., 2009. Proteomic and phenotypic profiling of the amphibian pathogen Batrachochytrium dendrobatidis shows that genotype is linked to virulence. Molecular Ecology 18, 415-429.

Fisher, M.C., Henk, D.A., Briggs, C.J., Brownstein, J.S., Madoff, L.C., McCraw, S.L., Gurr, S.J., 2012. Emerging fungal threats to animal, plant and ecosystem health. Nature 484, 186-194.

Flechas, S.V., Medina, E.M., Crawford, A.J., Sarmiento, C., Cárdenas, M.E., Amézquita, A., Restrepo, S., 2013. Characterization of the first Batrachochytrium dendrobatidis isolate from the Colombian Andes, an amphibian biodiversity hotspot. EcoHealth 10, $72-76$.

Gründler, M.C., Toledo, L.F., Parra-Olea, G., Haddad, C.F.B., Giasson, L.O.M., Sawaya, R.J., Prado, C.P.A., Araújo, O.G.S., Zara, F.J., Centeno, F.C., Zamudio, K.R., 2012. Interaction between breeding habitat and elevation affects prevalence but not infection load of Batrachochytrium dendrobatidis in Brazilian anuran assemblages. Diseases of Aquatic Organisms 97, 173-184.

Hajek, A.E., St. Leger, R.J., 1994. Interactions between fungal pathogens and insect hosts. Annual Review of Entomology 39, 293-322. 
Hall, C.A., Stanford, J.A., Hauer, F.R., 1992. The distribution and abundance of organisms as a consequence of energy balances along multiple environmental gradients. Oikos 65, 377-390.

Hunter, D.J., 2005. Gene-environment interactions in human diseases. Nature 6, 287298.

Hyatt, A.D., Boyle, D.G., Olsen, V., Boyle, D.B., Berger, L., Obendorf, D.,Colling, A., 2007. Diagnostic assays and sampling protocols for the detection of Batrachochytrium dendrobatidis. Diseases of Aquatic Organisms 73, 175-192.

Ignoffo, C.M., 1992. Environmental factors affecting persistence of entomopathogens. Florida Entomologist 516-525.

Inglis, T.J., Sagripanti, J.L., 2006. Environmental factors that affect the survival and persistence of Burkholderia pseudomallei. Applied and environmental microbiology 72, 6865-6875.

James, T.Y., Stenlid, J., Olson, A., Johannesson, H., 2008. Evolutionary significance of imbalanced nuclear ratios within heterokaryons of the basidiomycete fungus Heterobasidion parviporum. Evolution 62, 2279-2296.

James, T.Y., Litvintseva, A.P., Vilgalys, R., Morgan, J.A.T., Taylor, J.W., Fisher, M.C., Berger, L., Weldon, C., du Preez, L., Longcore, J.L., 2009. Rapid global expansion of the fungal disease chytridiomycosis into declining and healthy amphibian populations. PLoS Pathogens 5, 1-12.

James, T.Y., Toledo, L.F., Rödder, D., Leite, D.S., Belasen, A., Betancourt-Román, C.M., Jenkinson, T.S., Lambertini, C., Longo, A.V., Ruggeri, J., Collins, J.P., Burrowes, P., Lips, K.R., Zamudio, K.R., Longcore, J.E., 2015. Disentangling host, pathogen, and environmental determinants of a recently emerged wildlife disease: Lessons from the 
first 15 years of amphibian chytridiomycosis research. Ecology and Evolution, in press.

Knapp, R.A., Morgan, J.A.T., 2006. Tadpole mouthpart depigmentation as an accurate indicator of chytridiomicosys, an emerging disease of amphibians. Copeia 2, 188-197.

Kriger, K.M., Hines, H.B., Hyatt, A.D., Boyle, D.G., Hero, J. M., 2006. Techniques for detecting chytridiomycosis in wild frogs: comparing histology with real-time Taqman PCR. Diseases of Aquatic Organisms 71, 141-148.

Kriger, K.M., Ashton, K.J., Hines, H.B., Hero, J.M., 2007. On the biological relevance of a single Batrachochytrium dendrobatidis zoospore: a reply to Smith (2007). Diseases of Aquatic Organisms 73, 257-260.

Kriger, K.M., Hero, J., 2008. Altitudinal distribution of chytrid (Batrachochytrium dendrobatidis) infection in subtropical Australian frogs. Austral Ecology 33, $1022-$ 1032.

Kronstad, J.W., Attarian, R., Cadieux, B., Choi, J., D’Souza, C.A., Griffiths, E.J., Geddes, J.M.H., Hu, G., Jung, W.E., Kretschmer, M., Saikia, S., Wang, J., 2011. Expanding fungal pathogenesis: Cryptococcus breaks out of the opportunistic box. Nature 9, 193203.

La Marca, E., Lips, K.R., Lötters, S., Puschendorf, R., Ibáñez, R., Rueda-Almonacid, J. V., Young, B.E., 2005. Catastrophic population declines and extinctions in Neotropical harlequin frogs (Bufonidae: Atelopus). Biotropica 37, 190-201.

Lambertini, C., Rodriguez, D., Britto, F.B., Leite, D.S., Toledo, L.F., 2013. Diagnóstico do fungo quitrídio: Batrachochytrium dendrobatidis. Herpetologia Brasileira 2, 12 17. 
Lambowitz, A.M., Kobayashi, G.S., Painter, A., Medoff, G., 1983. Possible relationship of morphogenesis in pathogenic fungus, Histoplasma capsulatum, to heat shock response. Nature 303, 806-808.

Langhammer, P.F., Lips, K.R., Burrowes, P.A., Tunstall, T., Palmer, C.M., Collins, J.P., 2013. A fungal pathogen of amphibians, Batrachochytrium dendrobatidis, attenuates in pathogenicity with in vitro passages. PloS One, 8:e77630.

Lips, K.R., 1998. Decline of a tropical montane amphibian fauna. Conservation Biology 12, 106-117.

Liu, X., Rohr J.R., Li, Y.M., 2013. Climate, vegetation, introduced hosts and trade shape a global wildlife pandemic. Proceedings of the Royal Society B 280, 20122506.

Longcore, J.E., Pessier, A.P., Nichols, D.K., 1999. Batrachochytrium dendrobatidis gen. et sp. nov., a chytrid pathogenic to amphibians. Mycologia 91, 219-227.

Longo, A.V., Rodriguez, D., Leite, D.S., Toledo, L.F., Almeralla, C.M., Burrowes, P.A. Zamudio, K.R., 2013. ITS1 copy number varies among Batrachochytrium dendrobatidis strains: implications for qPCR estimates of infection intensity from field-collected amphibian skin swabs. PloS One 8, 1-10.

Matz, C., McDougald, D., Moreno, A.M., Yung, P.Y., Ylldlz, F.H., Kjelleberg, S., 2005. Biofilm formation and phenotypic variation enhance predation-driven persistence of Vibrio cholera. Proccedings of the National Academy of Sciences 102, 16819-16824.

Mitchell, K.M.,Churcher, T.S., Garner, T.W., Fisher, M.C., 2008. Persistence of the emerging pathogen Batrachochytrium dendrobatidis outside the amphibian host greatly increases the probability of host extinction. Proceedings of the Royal Society B 275, 329-334.

Murray, K.A., Retallick, R.W., Puschendorf, R., Skerratt, L.F., Rosauer, D., McCallum, H.I.,VanDerWal, J., 2011. Assessing spatial patterns of disease risk to biodiversity: 
implications for the management of the amphibian pathogen, Batrachochytrium dendrobatidis. Journal of Applied Ecology 48, 163-173.

Olson, D.H., Aanensen, D.M., Ronnenberg, K.L., Powell, C.I., Walker, S.F., Bielby, J., Fisher, M.C., 2013. Mapping the global emergence of Batrachochytrium dendrobatidis, the amphibian chytrid fungus. PloS One 8, 1-13.

Pavelka, N., Rancati, G., Zhu, J., Bradford, W.D., Saraf, A., Florens, L., Sanderson, B.W., Hattern, G.L., Li, R., 2010. Aneuploidy confers quantitative proteome changes and phenotypic variation in budding yeast. Nature 468, 321-325.

Piotrowski, J.S., Annis, S.L., Longcore, J.E., 2004. Physiology of Batrachochytrium dendrobatidis, a chytrid pathogen of amphibians. Mycologia 96, 9-15.

Piovia-Scott, J., Pope, K.L., Lawler, S.P., Cole, E.M., Foley, J.E., 2011. Factors related to the distribution and prevalence of the fungal pathogen Batrachochytrium dendrobatidis in Rana cascadae and other amphibians in the Klamath Mountains. Biological Conservation 144, 2913-2921.

Piovia-Scott, J., Pope, K., Worth, S.J., Rosemblum, E.B.,Poorten, T., Refsnider, J., Rollins-Smith, L., Reinert, L.K., Wells, H.L., Rejmanek, D., Lawler, S., Foley, J., 2014. Correlates of virulence in a frog-killing fungal pathogen: evidence from a California amphibian decline. The ISME journal 1-9.

Pounds, J.A., Bustamante, M.R., Coloma, L.A., Consuegra, J.A., Fogden, M.P., Foster, P.N., Young, B.E., 2006. Widespread amphibian extinctions from epidemic disease driven by global warming. Nature 439, 161-167.

Puschendorf, R., Carnaval, A.C., VanDerWal, J., Zumbado-Ulate, H., Chaves, G., Bolaños, F., Alford, R.A., 2009. Distribution models for the amphibian chytrid Batrachochytrium dendrobatidis in Costa Rica: proposing climatic refuges as a conservation tool. Diversity and Distributions 15, 401-408. 
Reed, T.E., Schindler, D.E., Waples, R.S., 2010. Interacting effects of phenotypic plasticity and evolution on population persistence in a changing climate. Conservation Biology 25, 56-63.

Rödder, D., Veith, M., Lötters, S., 2008. Environmental gradients explaining the prevalence and intensity of infection with the amphibian chytrid fungus: the host's perspective. Animal Conservation 11, 513-517.

Rödder, D., Kielgast, J., Bielby, J., Schmidtlein, S., Bosch, J., Garner, T.W., Lötters, S., 2009. Global amphibian extinction risk assessment for the panzootic chytrid fungus. Diversity 1, 52-66.

Rödder, D., Kielgast, J., Lötters, S., 2010. Future potential distribution of the emerging amphibian chytrid fungus under anthropogenic climate change. Diseases of Aquatic Organisms 92, 201-207.

Rohr, J.R., Halstead, N.T., Raffel, T.R., 2011. Modelling the future distribution of the amphibian chytrid fungus: the influence of climate and human-associated factors. Journal of Applied Ecology 48, 174-176.

Ron, S.R., 2005. Predicting the distribution of the amphibian pathogen Batrachochytrium dendrobatidis in the New World. Biotropica 37, 209-221.

Rosenblum, E.B., James, T.Y., Zamudio, K.R., Poorten, T.J., Ilut, D., Rodriguez, D., Eastman, J.M., Richards-Hrdlicka, K., Joneson, S., Jenkinson, T.S., Longcore, J.E., Parra Olea, G., Toledo, L.F., Arellano, M.L., Medina, E.M., Restrepo, S., Flechas, S.V., Berger, L., Briggs, Cheryl, J.,Stajich, J.E., 2013. Complex history of the amphibian-killing chytrid fungus revealed with genome resequencing data. Proceedings of the National Academy of Sciences 110, 9385-9390.

SAS. 2010. JMP, Version 10. SAS Institute Inc. (Cary, NC). 
Schloegel, L.M., Toledo, L.F., Longcore, J.E., Greenspan, S.E., Vieira, C.A., Lee, M., Zhao, S., Wangen, C., Ferreira, C.M., Hipólito, M., Davies, A.J., Cuomo, C.A., Dasdak, P., James, T.Y., 2012. Novel, panzootic and hybrid genotypes of amphibian chytridiomycosis associated with the bullfrog trade. Molecular Ecology 1-16.

Smits, W.K., Kuipers, O.P., Veening, J.W., 2006. Phenotypic variation in bacteria: the role of feedback regulation. Nature 4, 259-271.

Thoday, J.M., 1953. Components of fitness. Symposium of the Society for Experimental Biology 7, 96-113.

Travis, J. 1994. Evaluating the adaptive role of morphological plasticity. In Ecological morphology: Integrative Organismal in Biology (ed. P.C. Wainright \& S. M. Reilly), Chicago, IL: University of Chicago Press.

Valencia-Aguilar, A., Ruano-Fajardo, G., Lambertini, C., Leite, D.S., Toledo, L.F., Mott, T., 2015. Chytrid fungus acts as a generalist pathogen infecting species-rich families in Brazilian rainforests. Diseases of Aquatic Organisms 114, 61-67.

Vercelli, D., 2004. Genetics, epigenetics, and the environment: switching, buffering, releasing. Journal of Allergy and Clinical Immunology 113, 381-386.

Vieira, C.A., Toledo, L.F., 2012. Isolamento, cultivo e armazenamento do fungo quitrídio: Batrachochytrium dendrobatidis. Herpetologia Brasileira 1, 18-19.

Voyles, J., Johnson, L.R., Briggs, C.J., Cashins, S.D., Alford, R.A., Berger, L., Rosenblum, E.B., 2014. Experimental evolution alters the rate and temporal pattern of population growth in Batrachochytrium dendrobatidis, a lethal fungal pathogen of amphibians. Ecology and Evolution 4, 3633-3641.

Wake, D.B., Vredenburg, V.T., 2008. Are we in the midst of the sixth mass extinction? A view from the world of amphibians. Proceedings of the National Academy of Sciences 105, 11466-11473. 
Walker, S.F., Bosch, J., Gomez, V., Garner, T.W., Cunningham, A.A., Schmeller, D.S. Fisher, M.C., 2010. Factors driving pathogenicity vs. prevalence of amphibian panzootic chytridiomycosis in Iberia. Ecology Letters 13, 372-382.

Woodhams, D.C., Alford, R.A., Briggs, C.J., Johnson, M., Rollins-Smith, L., 2008. Lifehistory trade-offs influence disease changing climates: strategies of an amphibian pathogen. Ecology 89, 1627-1639.

Zaragoza, O., García-Rodas, R., Nosanchuk, J.D., Cuenca-Estrella, M., RodríguezTudela, J.L., Casadevall, A., 2010. Fungal cell gigantism during mammalian infection. PLoS Pathogens 6, 1-18. 


\section{Figure legends}

Figure 1. Correlation between field estimates of prevalence and infection intensity at our five focal sites. The line is only for visualization, not indicating regression adjustment.

Figure 2. Correlation between mean zoospore and zoosporangium sizes for five Batrachochytrium dendrobatidis strains isolated from a $500 \mathrm{~m}$ elevational range in the Brazilian Atlantic Forest. The line represents only a tendency without any model adjustment.

Figure 3. Positive association of Batrachochytrium dendrobatidis mean zoosporangium size with prevalence (A) and infection intensity (B) along an elevational range. The line represents only a tendency without any model adjustment.

Figure 4. Size Index and Infection Index are positively related across five focal sites in the Brazilian Atlantic Forest. The line represents only a tendency without any model adjustment. 
Table 1. Batrachochytrium dendrobatidis strains isolated along a $500 \mathrm{~m}$ elevational gradient, with the number of adult Hylodes phyllodes sampled at each elevation, prevalence, infection intensity, zoospores and zoosporangia sizes, and final zoospore number in culture during the growth experiment. Values are mean \pm standard deviation (range).

\begin{tabular}{|c|c|c|c|c|c|c|c|}
\hline Strain & Elevation (m) & $\mathrm{N}$ adults & Prevalence (\%) & $\begin{array}{c}\text { Infection intensity } \\
\text { (zoospore equivalents) }\end{array}$ & $\begin{array}{c}\text { Zoospore size } \\
(\mu \mathrm{m})\end{array}$ & $\begin{array}{c}\text { Zoosporangia } \\
\text { size }(\mu \mathrm{m})\end{array}$ & $\begin{array}{c}\text { Zoospore number } \\
\text { day } 9\left(\times 10^{7}\right)\end{array}$ \\
\hline CLFT 034 & 271 & 20 & 70.00 & $\begin{array}{l}466.09 \pm 1097.04 \\
(1.68-3330.08)\end{array}$ & $\begin{array}{c}3.87 \pm 0.63 \\
(2.90-5.24)\end{array}$ & $\begin{array}{c}21.54 \pm 6.06 \\
(10.80-35.76)\end{array}$ & $\begin{array}{c}3.9 \pm 5 \\
(3.2-4.5)\end{array}$ \\
\hline CLFT 033 & 309 & 20 & 90.00 & $\begin{array}{l}862.63 \pm 1889.18 \\
(5.58-6633.34)\end{array}$ & $\begin{array}{c}4.08 \pm 0.67 \\
(2.84-5.54)\end{array}$ & $\begin{array}{c}22.29 \pm 4.96 \\
(14.73-38.58)\end{array}$ & $\begin{array}{c}1.0 \pm 3 \\
(6-1.3)\end{array}$ \\
\hline CLFT 030 & 558 & 36 & 58.33 & $\begin{array}{l}167.43 \pm 810.64 \\
(1.05-4574.47)\end{array}$ & $\begin{array}{c}3.56 \pm 0.67 \\
(2.01-5.03)\end{array}$ & $\begin{array}{c}16.18 \pm 3.01 \\
(10.94-26.52)\end{array}$ & $\begin{array}{c}2.2 \pm 3 \\
(1.7-2.6)\end{array}$ \\
\hline CLFT 032 & 670 & 14 & 92.86 & $\begin{array}{l}798.46 \pm 1888.40 \\
(10.37-6933.59)\end{array}$ & $\begin{array}{c}4.37 \pm 0.91 \\
(2.69-6.34)\end{array}$ & $\begin{array}{c}24.42 \pm 8.00 \\
(14.09-45.05)\end{array}$ & $\begin{array}{l}4.2 \pm 2.0 \\
(2.8-7.2)\end{array}$ \\
\hline
\end{tabular}


Figure 1

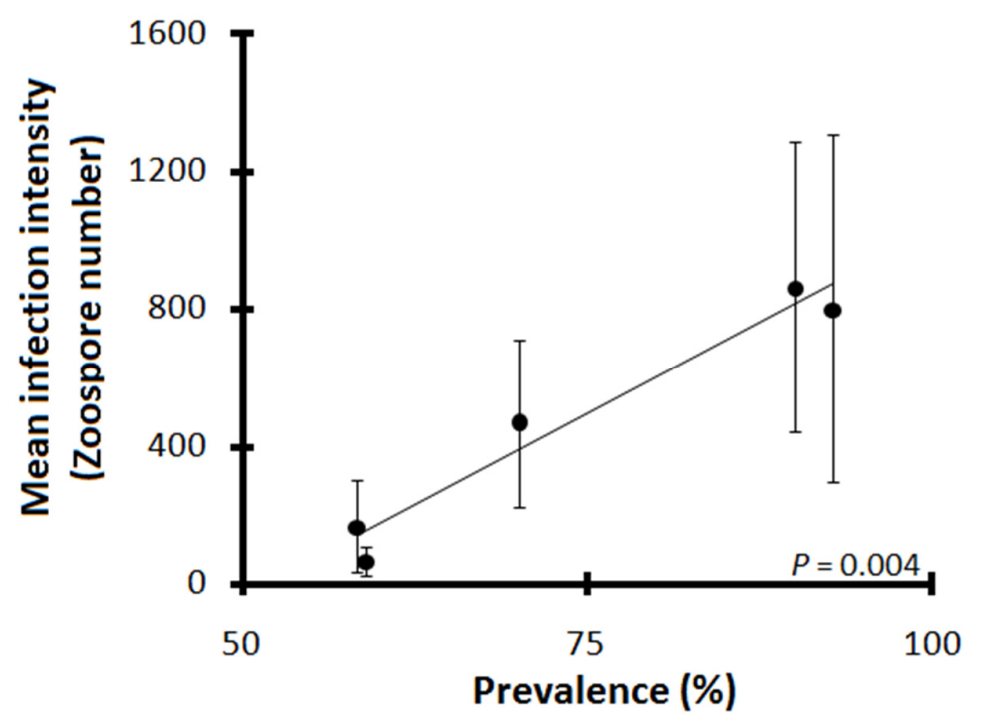


Figure 2

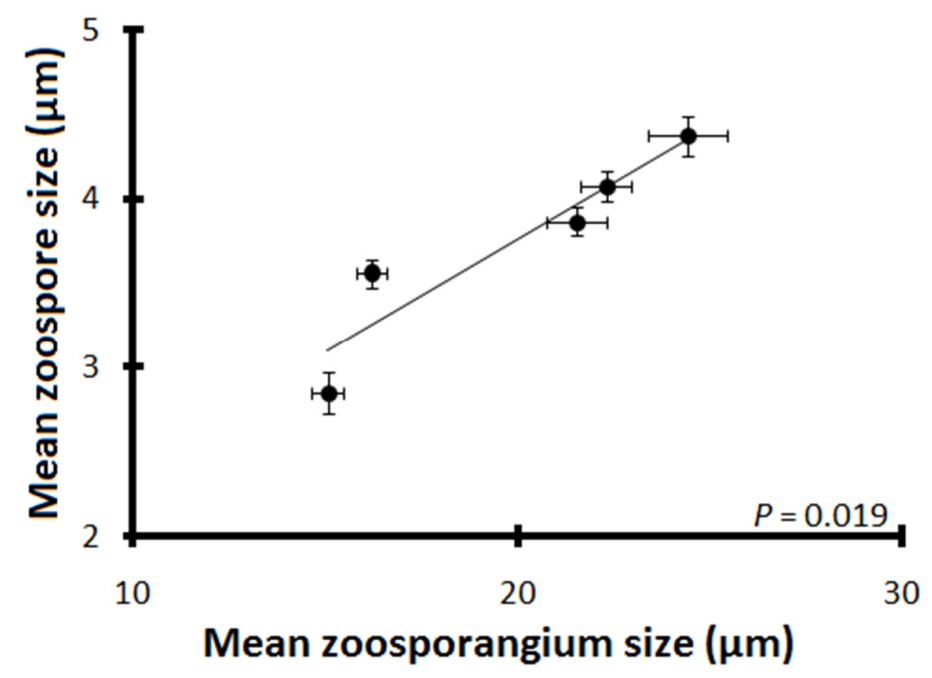


Figure 3
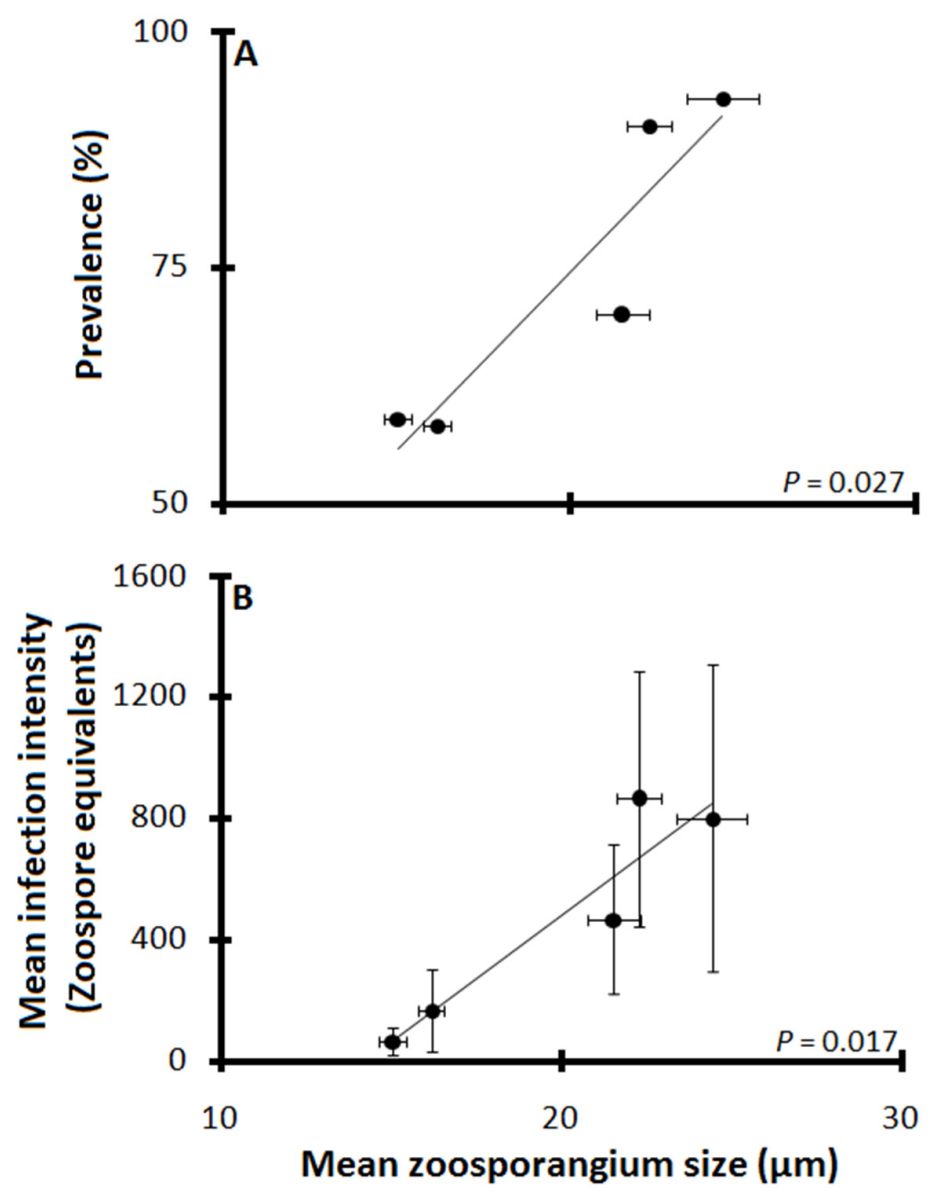
Figure 4

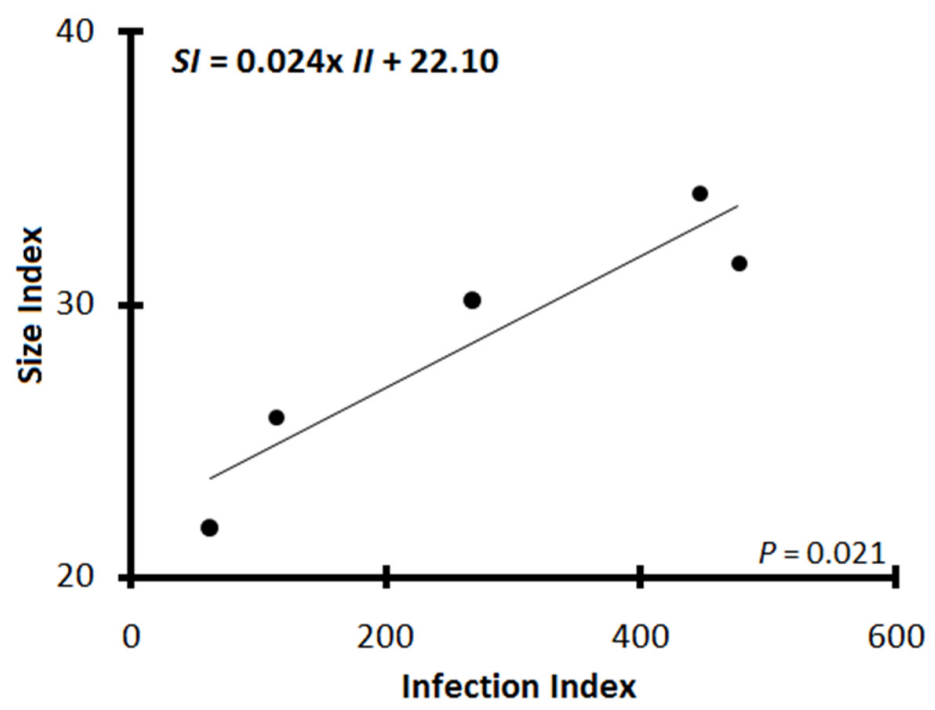

